\title{
Population declines of the endangered endemic birds on Grenada, West Indies
}

\author{
DAVID E. BLOCKSTEIN
}

\section{Summary}

The Grenada Dove Leptotila wellsi and the Grenada Hook-billed Kite Chondrohierax uncinatus mirus have each apparently declined since initial surveys in 1987. In a midwinter $1989 / 1990$ census I estimated that there were $75-85$ Grenada Doves, compared with 100 in 1987. The $1989 / 1990$ numbers include two small populations not located in 1987 . The main population may have declined by $40-50 \%$ since 1987 . Half as many Hook-billed Kites were seen in $1989 / 1990$ as in 1987 when I estimated the total population to be $15-30$. Although seasonal factors may be responsible for some of the differences, destruction of habitat has led to real declines. Unless the prime habitat is protected, extinction of both birds is likely.

\section{Introduction}

Grenada $\left(310 \mathrm{~km}^{2}\right)$ is the southernmost island $\left(12^{\circ} \mathrm{N} 61^{\circ} \mathrm{W}\right)$ of the Lesser Antilles. Two of the 35 resident species of land birds, the Grenada Dove Leptotila wellsi and the Grenada Hook-billed Kite Chondrohierax uncinatus mirus are at risk of extinction, both being treated as endangered in U.S. legal definition (USFWS 1987) and as "Indeterminate" and "Endangered" respectively in IUCN categorisation (King 1978-1979). The Grenada Dove had been regarded as a distinct species since it was first described (Lawrence 1884, Wells 1886) until, despite a lack of evidence from living specimens, it was recently reclassified as a subspecies of the Grey-fronted Dove L. rufaxilla of South America (AOU 1983). I subsequently showed that $L$. wellsi and $L$. rufaxilla have distinct songs and show important differences in plumage, and have argued that $L$. wellsi should be regarded as a full species endemic to the island of Grenada (Blockstein and Hardy 1989). The Grenada Hook-billed Kite is an endemic subspecies of a widely distributed species (Smith and Temple 1982a).

The Grenada Dove has long been considered to be rare (Devas 1943). It is confined to the dry woodlands of south-west Grenada and on the west coast (Lack and Lack 1973, Wunderle 1985, Blockstein 1988). In 1987, in the first study of its biology and status, I located 49 singing males on the south-west peninsula with the majority of the population on the wooded hillsides of the Mt Hartman estate (Blockstein 1988).

Hook-billed Kites have apparently also been uncommon on Grenada for at least 100 years (Wells 1886, Blockstein 1988). Found primarily in southern Grenada, their distribution appears to be determined largely by the distribution of the two species of forest-dwelling snails upon which they feed (Smith and Temple 1982b). In 1987, I estimated that 15-30 kites were extant on Grenada. 
The purpose of this study was to assess population changes in the doves and kites, further evaluate habitat preferences and encourage the Grenadians to implement conservation measures recommended in 1987 (see Blockstein 1988).

\section{Study area}

Fieldwork from 13 December 1989 to 28 January 1990 was concentrated in areas of lowland dry scrub woods that are the preferred habitat of both species. I was ably assisted throughout the study by Grenadian field assistants Andy Murrell and Elizabeth Niles. We spent three weeks in the south-west peninsula, with most effort centred at the $2 \mathrm{~km}^{2}$ government-owned Mt Hartman estate, which is the only large area of undeveloped land in the south-west peninsula. The wooded area of Mt Hartman occurs largely on two ridges, which are covered with deciduous thorn-scrub thickets with scattered emergent trees. The front ridge curves from north-east to south and is bordered by agricultural clearings on both sides. The second (back) ridge to the east of the main ridge is oriented south-westerly and is bordered by a bay on the east. Most of the ridge-tops are $125 \mathrm{~m}$ above sea-level.

We spent 10 days along the west coast, mostly on the wooded hillsides of the Beausejour estate and at Halifax Harbor. The other wooded sites along the west coast were also searched. The Beausejour estate has large areas of mature lowland forest and about 2 ha of secondary scrub woodlands dominated by leguminous saplings. Halifax Harbor contains a $400 \mathrm{~m}$ wide band of secondary scrub woodlands with a partially closed canopy at $6-8 \mathrm{~m}$, between elevations of $50-150 \mathrm{~m}$. Much of the understorey consists of dense shrubs. Mature lowland forest occurs on the very steep hillside above $150 \mathrm{~m}$. The site is bordered by the main west coast highway and a large open dump below the roadway.

We spent two weeks in the Levera area of north-east Grenada. The core of this area has been designated as a national park, which consists of the brackish 5 ha Levera Lake and its surrounding mangroves and the $800 \mathrm{~m}$ high Levera Hill. The sides of the hill are forested with some clearing for agriculture. The north-east corner of Grenada is a mosaic of clearings, dense shrub in former clearings, and successional forest which is taller and less thorny than in the south-west. We also visited Levera (Sugarloaf) Island and Sandy Island, off the north-east coast.

\section{Methods}

We searched all areas of potential habitat by walking trails, roads and through the forest listening for singing male doves. Each time we encountered a dove, I marked its location on map and noted its habitat and behaviour. The methods were a repeat of my earlier work in Grenada (Blockstein 1988). We checked all locations where Grenada Doves had been located in 1987 as well as additional areas that seemed suitable. Because songs are audible for more than $100 \mathrm{~m}$, and singing continued throughout the study period, it is likely that few doves were missed. We also played back tape-recorded songs of $L$. wellsi in attempts to elicit responses from unseen doves.

We conducted 10-minute point-counts at Mt Hartman $(n=35)$ and Levera $(n=77)$. At each count the three observers stood $25 \mathrm{~m}$ apart with the author in 
the centre and marked the location of all individual birds of all species seen or heard in a 10-minute interval. The location of each bird was noted either inside or outside a $25 \mathrm{~m}$ radius circle formed by the observers. This is a modification of the fixed-radius point-count (Hutto et al. 1986). Point-counts were conducted between $06 h_{30}$ and 10 hoo. All points were at least $100 \mathrm{~m}$ (usually $150 \mathrm{~m}$ ) apart and scattered to provide complete coverage of the habitat.

At each point we recorded the following vegetation parameters: dominant species, diameter of the four largest trees within $10 \mathrm{~m}$ of the point, per cent ground cover, per cent shrub cover, per cent canopy cover, and estimated canopy height. Per cent cover was estimated by taking one reading at the point and six readings at $2 \mathrm{~m}$ intervals in each of the four cardinal directions. For each reading, I sighted through a vertical tube and rated each layer of vegetation on a scale of o (no vegetation) to 4 (complete cover). When summed, these readings provided a measure of cover on a scale of o to $100 \%$.

Data on Hook-billed Kites were collected opportunistically. Whenever we saw a kite, I noted its location, behaviour, sex and plumage. We observed each kite until it moved out of sight.

\section{Results}

\section{Grenada Dove}

Population and distribution A total of 38 to 43 singing males were located, with 25 to 30 in the south-west peninsula (Table 1). Almost all of the south-west peninsula birds were located on the wooded ridges of the Mt Hartman estate (Figure 1). Furthermore, $90 \%$ of the doves at Mt Hartman were concentrated on $1 \mathrm{~km}$ of the main ridge. Only two doves were located in the south-west peninsula away from Mt Hartman.

Additional populations were located on the west coast. We found three males and two females in young forest at the Beausejour estate. An additional 1o singing males occupied the lower hillsides at Halifax Harbor. One of these was later seen attending a nest. There were four males along the hillside on each side of the Salle River which empties into Halifax Harbor. Their territories were more or less linear. Two males were heard singing along the Douce River, which also empties into Halifax Harbor.

No Grenada Doves were found in north-east Grenada or on the offshore islets. If the sex ratio is approximately $1: 1$, and if their census was an accurate reflection of reality, the total population of Grenada Doves is only $75-85$ individuals.

Table 1. Recent population counts of Grenada Doves ${ }^{a}$

\begin{tabular}{lcccccccc}
\hline & \multicolumn{3}{c}{ South-west peninsula } & & \multicolumn{2}{c}{ West coast } & \\
& Mt Hartman & Other & Total & & Halifax Harbor & Beausejour & \multirow{2}{*}{ Grand total } \\
\hline $1987^{\mathrm{b}}$ & 39 & 10 & 49 & & - & - & 49 \\
$1988^{\mathrm{c}}$ & 32 & 5 & 37 & & - & - & 37 \\
$1988^{\mathrm{d}}$ & 25 & 4 & 29 & & - & - & 29 \\
$1989-1990^{\mathrm{e}}$ & $23-28$ & 2 & $25-30$ & & 10 & 3 & $38-43$ \\
\hline
\end{tabular}

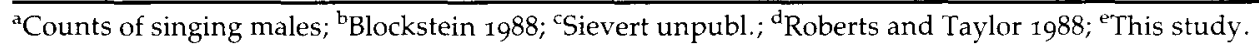




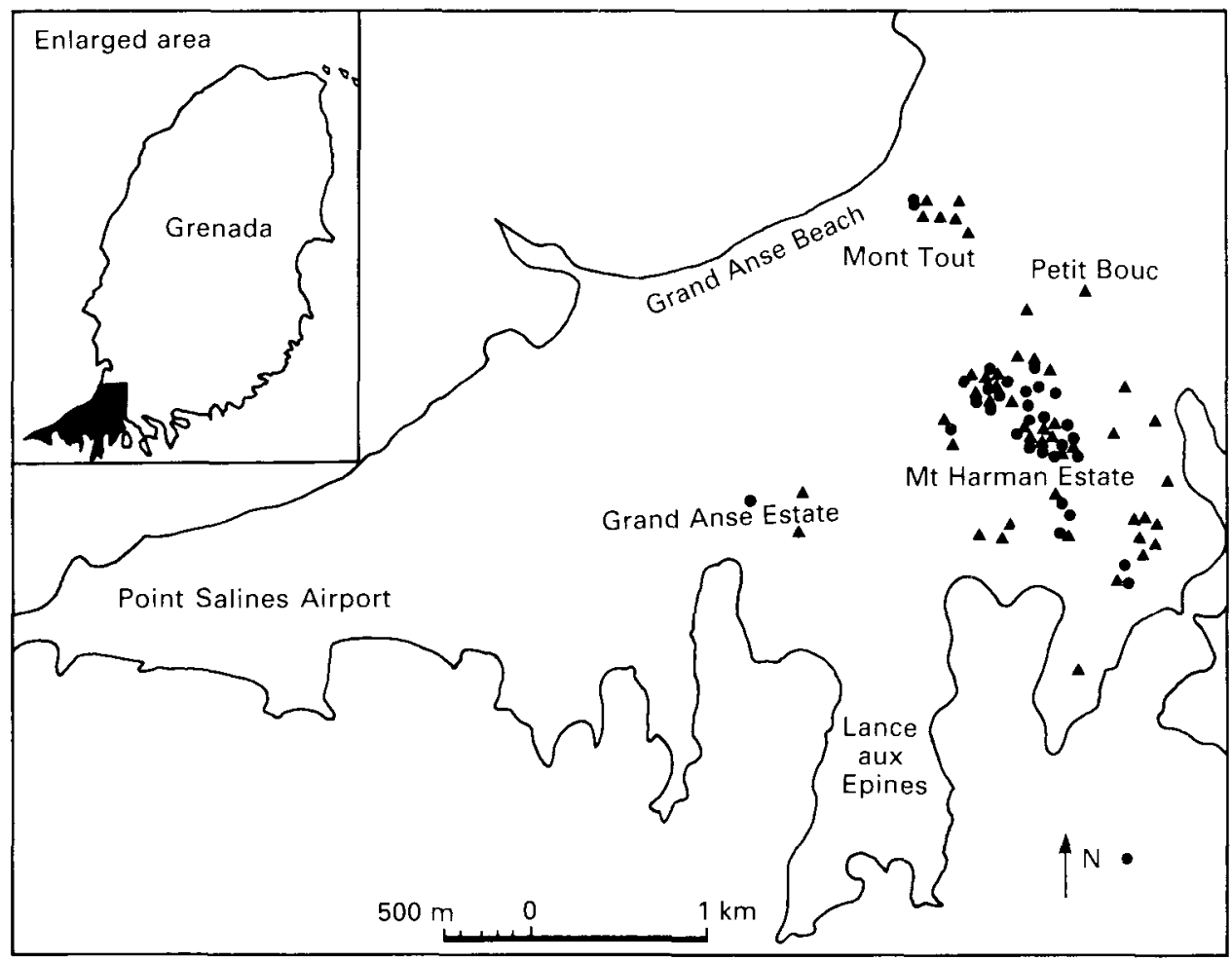

Figure 1. Distribution map of Grenada Doves in south-west Grenada. Filled triangles, individuals located in 1987; filled circles, individuals located in 1989/1990.

Habitat Grenada Doves were found on four (35\%) of the point-counts at the Mt Hartman estate and none at Levera. Points with doves had a mean canopy height of $7.6 \pm 0.4 \mathrm{~m}$ [SD] $(n=4)$ as opposed to $5.9 \pm 0.1 \mathrm{~m}$ [SD] $(n=30)$ for points without doves at Mt Hartman. Points with doves had significantly more canopy cover $(55.8 \pm 9.9 \%$ versus $31.6 \pm 0.6 \%, P<0.005)$, less shrub cover $(56.5$ $\pm 4.75 \%$ versus $67.2 \pm 0.5 \%)$ and less herb cover $(21.5 \pm 3.7 \%$ versus $27.9 \pm$ $0.5 \%)$.

The areas that contained Grenada Doves were characterised by a fairly closed canopy, large areas of bare ground, and a substantial shrub component. As in 1987 (Blockstein 1988), no Grenada Doves were seen outside the forest although some were observed foraging near the edge of clearings. The leguminous sapling "campesh" was the dominant species in the woods. When viewed from a distance, the hillsides where the doves occurred were a lighter shade of green than the higher elevation forest. No forest at Levera seemed to match the qualitative features of the occupied habitat, although the east slope of Levera Hill had a closed canopy and open ground.

Behaviour All doves seen were walking on the ground or calling from perches. Foraging occurred only on the ground. Birds pecked at the ground but it was impossible to see what they were eating, although they were probably taking seeds. 
The doves appear to be territorial. It was possible to locate singing males in the same location daily. On 31 December I viewed a probable territorial encounter between two males. Each had been singing from perches about $30 \mathrm{~m}$ apart at opposite ends of a clearing. One flew and landed in a bush $5 \mathrm{~m}$ from the other and then flew to the ground directly beneath the other. The second dove immediately flew down to the first; one gave a throaty vocalisation and both proceeded to walk rapidly, one after the other. For the next 20 minutes they continued to walk rapidly, frequently stopping to jump at each other and strike with the wings. Some 50-100 blows were struck. No additional vocalisations were heard. Finally one flew off, followed by the other.

Breeding We located a nest with eggs at Halifax Harbor. It was on a palm frond $4 \mathrm{~m}$ above the ground. On 1 January I saw a male singing from the frond. On 22 January Elizabeth Niles saw a dove get onto the frond, which I realised harboured a nest. The egg or eggs had not hatched when I left on 27 January. Niles and Murrell continued to check the nest. On 13 February they observed a nestling, which was a week or less old, based on their description of its downy feathers and inability to stand upright. On 16 February the nest was still active, but empty on 20 February. It is unknown whether there had been more than one egg or nestling, or whether any young had fledged. No other nests were found although a pair were sitting side-by-side in a bush at Beausejour.

It is likely that the breeding season is longer on the west coast than in the xeric south-west peninsula. The west coast continued to receive rain throughout the study period, while the trees and many of the shrubs had lost their leaves by mid-January in the seasonally deciduous south-west shrub woodlands. Singing by the doves was very intense throughout the period on the west coast, but became sporadic in the south-west by late December. The only other known nest of Grenada Doves was being built in July 1988 at Mt Hartman (P. Sievert pers. comm.).

\section{Hook-billed Kite}

Population and distribution I made a total of 17 sightings of Hook-billed Kites in the south-west peninsula. These represent a minimum of four birds at Mt Hartman, based on simultaneous sightings. It is not known whether single kites seen 1$2 \mathrm{~km}$ from Mt Hartman were the same individuals. I did not see kites in other parts of southern Grenada, nor along the west coast.

Andy Murrell located a pair of kites near Levera Lake in north-east Grenada. This pair could reliably be found in the same area for at least five days after they were first located. Kite-broken snail shells were found in one other site in northeast Grenada. These shells were not recent, and no kites were seen there.

Behaviour All but three of the sightings in the south-west peninsula were of flying birds. Most soared only briefly and were travelling from place to place. During one four-hour watch on a day with excellent thermals only a single kite was seen. It rose high on the thermals and made a stunning dive about two minutes later, but did not reappear. In contrast, from one to three Broad-winged Hawks Buteo platypterus were soaring almost constantly during the watch. 
Two kites were seen foraging on land snails at Mt Hartman. The Levera pair also fed on land snails, which they took by making short flights in a tree and grabbing the snail with its bill (Smith and Temple 1982b, Blockstein 1988). Snails with the breakage pattern typical of being extracted by kites were of the same species observed in 1987 (Blockstein 1988).

Breeding We saw no evidence of nesting or courtship. The pair at Levera sat together on one day, but otherwise were observed separately. One juvenile bird was moulting into adult plumage. It had a dark blue back and dark brown wings with considerable white "flecking". Its breast was streaked, unlike the horizontal barring of the adults.

\section{Discussion}

Populations of both species appear to have declined substantially since 1987 (Table 1). It is possible that some Grenada Doves were missed due to a reduced rate of singing in the early dry season. However, the counts of the Mt Hartman population in 1988 (Sievert unpubl., Roberts and Taylor 1988) were already lower than in 1987. This is due largely to a loss of individuals on the back ridge. Indeed, the population on the front ridge was denser than in 1987 .

Much of this change is probably due to habitat alteration. In July 1987 at the end of my previous study (Blockstein 1988), the lower slopes of the back ridge were being bulldozed for a government-subsidised sugarcane plantation. By 1989 essentially all of the lowlands at Mt Hartman had been planted in cane. This has had the residual effect of forcing subsistence farmers to make their gardens on the lower slopes that had been shrubland in 1987. Additionally, local people who cut saplings and brush for charcoal production have cut higher onto the hillside. Thus, not only has the quantity of suitable habitat declined, but habitat quality has deteriorated too.

The virtual disappearance of the satellite populations on the south-west peninsula outside Mt Hartman may be due to several factors. Some habitat destruction has occurred along Mont Tout, but there appear to be no major changes since 1987 . It is possible that the decline of this subpopulation from eight singing males in 1987 to one in $1989 / 1990$ is simply due to stochastic events in the small population. It is also possible that other males were present but silent.

The small populations along the west coast had been noted previously. Lack and Lack (1973) saw one Grenada Dove at Beausejour in 1971. The present population of three males and two females appears to be doomed. They are in a small patch of habitat, the only piece of second-growth saplings in the area, and clearing for a new housing development was taking place next to this patch. I did not investigate this area in 1987.

Wunderle (1985) heard five Grenada Doves at Halifax Harbor in 1981. I stopped at this site only briefly in 1987 and did not hear any doves. The 1o males, with at least one nest, found in 1989/1990 constitute an important buffer to the Mt Hartman population. The two populations probably have been distinct throughout historical times, as they are separated by $10 \mathrm{~km}$ including the capital city of St. George's and the doves appear to be highly sedentary. It is likely that 
there has until recently been some exchange between the populations at Halifax Harbor and Beausejour which are $1 \mathrm{~km}$ apart. However, the intervening woodlands are now largely fragmented and degraded due to human dwellings.

Our search at Levera and the offshore islands was complete enough to conclude that no Grenada Doves exist on the north-east corner of Grenada. Grenada Doves had been found at Levera in the period 1960-1977 according to a local birdwatcher (see Blockstein 1988), but I did not find them in three days of searching in 1987. Although no habitat appears to match the features of the areas occupied by Grenada Doves, it may be possible to restore some of the abandoned pastures into suitable habitat. Habitat restoration in this protected area coupled with translocation of individuals raised in the extant populations, supplemented by captive breeding, is an expensive but possible option for preserving Grenada Doves (see Recommendations).

The population biology of the Grenada Hook-billed Kites remains enigmatic. The kites are difficult to census because of their inconspicuous behaviour and a lack of knowledge of their home-range size. I saw approximately half as many kites in 1989/1990 as in 1987, in roughly equal search time (Blockstein 1988). It is the impression of a local birdwatcher that my 1987 study coincided with the peak of abundance for these birds (Peter Hall pers. comm.). Until someone makes a detailed study of the kites including description of individual plumage and use of radio telemetry, population estimates will remain imprecise.

If the kite population has declined in southern Grenada, it is probably not due to a lack of food. Snails of their principal prey species (Bulimulus wiebesi) were abundant, although few shells showed the breakage pattern typical of predation by kites (Smith and Temple 1982b).

The pair sighted at Levera were the first documented sightings in northern Grenada since the 1970 s (see Blockstein 1988). Both prey species of snails were present in the area.

\section{Recommendations}

Recommendations for the conservation of Grenada's endangered birds have not yet been implemented (Blockstein 1988). It is absolutely crucial that habitat destruction at Mt Hartman be stopped and that the Halifax Harbor hillsides be protected. If this is not done, remedial methods may be unable to save the Grenada Dove. My specific recommendations are that there should be:

(1) Designation of the Mt Hartman estate as a national critical conservation area and natural landmark (Government of Grenada/Organization of American States 1988), involving (a) the lease of wooded ridges to a group such as Grenada National Trust, perhaps through an international conservation group for a nominal fee, as the lowlands have been leased for agriculture at US\$1/acre; (b) prohibition of additional clearing of wooded hillsides and brush at Mt Hartman; (c) authorisation of the government forestry department to work in lowland dry forests such as Mt Hartman, including reforestation of trees for charcoal and for cattle browse, community forestry and extension work; (d) appointment of a warden to enforce the prohibition on clearing of forest and brush on Mt Hartman's ridges; 
(2) Similar designation of the hills around Halifax Harbor as a national critical area;

(3) Strict enforcement of the moratorium against building on ridge-tops in the south-west peninsula;

(4) Stationing of a conservation biologist in Grenada for two years to continue research and conduct a public education programme regarding native wildlife of Grenada, especially endangered species;

(5) Updating wildlife law in Grenada, especially prohibiting shooting of hawks;

(6) Appointment of a government wildlife conservation and management officer;

(7) Continued census and monitoring of dove, kite and other bird species;

(8) Restoration of degraded drylands in and around Levera National Park with an ultimate aim of restoring populations of Grenada Doves to the area.

\section{Acknowledgements}

This study was supported by: World Wildlife Fund-U.S., International Council for Bird Preservation (Pan American Continental Section), U.S. Fish and Wildlife Service, Organization of American States, and the American Federation of Aviculture, and was conducted in cooperation with the Government of Grenada, Ministry of Agriculture, National Parks Program. I owe tremendous thanks to Elizabeth Niles and Andy Murrell for their excellent assistance in the field. Thanks also to Kennedy Calliste, George Vincent, Peter Hall, Michael Richie, Mathew Wigglesworth and Maria Niles for assistance in Grenada. Stanley A. Temple of the University of Wisconsin suggested this project and provided support for the initial field research. Andrew Roberts, Lynette Taylor, and Paul Sievert provided additional monitoring during my absence from Grenada.

\section{References}

American Ornithologists' Union (1983) Check-list of North American birds. Sixth edition. Washington, D.C.: American Ornithologists' Union.

Blockstein, D. E. (1988) Two endangered birds of Grenada, West Indies: Grenada Dove and Grenada Hook-billed Kite. Caribbean J. Sci. 24: 127-136.

Blockstein, D. E. and Hardy, J. W. (1989) The Grenada Dove (Leptotila wellsi) is a distinct species. Auk 106: 334-340.

Devas, R. P. (1943) Birds of Grenada, St. Vincent and the Grenadines. (Reprinted by Carenage Press, St. George's, Grenada.)

Government of Grenada and Organization of American States (1988) Plan and policy for a system of national parks and protected areas in Grenada and Carriacou. Washington, D.C.: Organization of American States.

Hutto, R. L., Pletschet, S. M. and Hendricks, P. (1986) A fixed-radius point-count method for nonbreeding and breeding season use. Auk 103: 593-602.

King, W. B. (1978-1979) Red Data Book, 2. Aves. Second edition. Morges, Switzerland: International Union for Conservation of Nature and Natural Resources.

Lack, D. and Lack, A. (1973) Birds on Grenada. Ibis 115: 53-59.

Lawrence, G. N. (1884) Characters of a new species of pigeon of the genus Engyptila from the island of Grenada, West Indies. Auk 1: 180-184.

Roberts A. W. P. and Taylor, L. J. (1988) The Grenada Dove expedition. Reading, U.K.: University of Reading unpublished report. 
Smith, T. B. and Temple S. A. (1982a) Feeding habits and bill polymorphism in Hookbilled Kites. Auk 99: 197-207.

Smith, T. B. and Temple, S. A. (1982b) Grenada Hook-billed Kites: recent status and life history notes. Condor 84: 131.

U.S. Fish and Wildlife Service (1987) Endangered and threatened wildlife and plants. U.S. Government Printing Office 5o CFR 17.11 and 17.12.

Wells, J. G. (1886) A catalog of the birds of Grenada, West Indies, with observations thereon. Proc. U.S. Natn. Mus. 9: 609-633.

Wunderle, J. M. (1985) An ecological comparison of the avifaunas of Grenada and Tobago, West Indies. Wilson Bull. 97: 356-365.

DAVID E. BLOCKSTEIN

American Institute of Biological Sciences, 730 11th St. NW, Washington D.C. 20001, U.S.A. 